\title{
System a metasystemowe myślenie bycia Martina Heideggera
}

\author{
DOI: http://dx.doi.org/10.12775/RF.2016.024
}

Pojęcie systemu pojawiło się w kontekście metodyczności, naukowości i systematyczności filozofii. Systematyczność charakteryzuje metodę filozofii. Filozofia jako nauka musi być systematyczna. Pytaniem jest, czy systematyczność filozofii ma wypływać z systemu zasad, tworzących całość systemową związanych z zasadą podstawowa, czy też filozofia może być systematyczna, rezygnując z systemu. Heideggera myślenia nie można zaliczyć ani do myślenia systemowego, ani asystemowego. Filozofowanie Heideggera jest „metasystemowe”.

Słowo "system" pojawiło się po raz pierwszy w starożytności grec$\mathrm{kiej}^{1}$. Greckie słowo sistema oznacza: zestawienie razem. Zródłowe, grec-

1 Słowo sistema występuje zarówno w antycznej literaturze, jak i w specyficznie filozoficznym znaczeniu. Dla filozoficznego rozumienia szczególnie ważne jest zastosowanie słowa sistema w medycynie (Corpus Hippokraticum), na przykład, jako miarowe uderzenia pulsu i w teorii muzyki jako systemu interwałów w skali tonów. Pierwotnie pojęcie „systemu” miało związek z rytmicznościa, regularnościa, powtarzalnością. Pierwsze filozoficzne użycie terminu sistema znajduje się w dialogu Platona Fileb. Fragment ten traktuje o dialektyce między tym, co pojedyncze i wielościa, między tym, co ma granice i tym, co jest nieograniczone, prowadzącej do rozumienia kosmologicznej koncepcji świata jako całości. W pseudoplatońskim dialogu Epinom, termin ten jest używany w kontekście kosmologicznym jako system liczb służący mierniczo do matematycznego ujęcia poruszania się gwiazd. Tak, jak Platon stosuje w Prawach słowo „system” na oznaczenie sprzymierzenia się trzech państw doryckich, tak samo Arystoteles używa pojęcia „systemu” w znaczeniu politycznym, kiedy w Etyce Nikomachejskiej mówi o systemie zorganizowanej wspólnoty jako polis. Zasadniczo jednak posługuje się Arystoteles terminem "system” w De generalis animals, 
kie znaczenie systemu można, w wykładni Heideggera, rozumieć przynajmniej w trojaki sposób.

Układam coś w pewien porządek nie tylko w taki sposób, że to, co jest dane i napotkane, zostaje, według już danej siatki pozycji, na niej rozdzielone i umiejscowione - jak choćby szyba wstawiana w gotową ramę okienną - lecz zestawiam w porządek w taki sposób, że sam porządek zostaje przy tym dopiero projektowany ${ }^{2}$.

To, co porządkowane, staje się widoczne w jedności własnej struktury. Porządek decyduje o rozmieszczeniu, a sposób rozlokowania tego, co uporządkowane, wpływa na porządek. Porządek wraz z tym, co uporządkowane, tworzą jedność. Cała struktura porządkowa tworzy jakby żywą istotę. Sistema tou sistemata. W tym sensie mówi się o systemie nerwowym, systemie oddychania, także o systemach militarnych, na przykład, greckiej lub rzymskiej zamkniętej formacji bojowej phalanx.

Jednak 'zestawienie razem' może też oznaczać jedynie: zsuwam ze sobą dowolne z dowolnym - także bez danej uprzednio siatki porządkującej jak popadnie i bez końca. Odpowiednio do tego, sistema może również znaczyć: zwykłe nagromadzanie i sztukowanie. Między tymi skrajnymi przeciwieństwami znaczenia (systemu) - wewnętrzne spoiwo (Fuge) i zwykłe zsuwanie (Geschiebe) - sytuuje się to (znaczenie), według którego system znaczy: rama, żaden wewnętrzny porządek, ani też żadne czysto zewnętrzne dosztukowywanie ${ }^{3}$.

Tak więc system może zasadniczo oznaczać: 1) wewnętrzną strukturę, względnie układ porządkujący wraz z tym, co uporządkowane: wewnętrzne złożenie; 2) czysto zewnętrzny układ i 3) konstrukcję ramową jako coś pośredniego między tymi dwoma znaczeniami systemu. U starożytnych Greków można znaleźć wszystkie trzy wyróżnione znaczenia, które wpłynęły decydująco na późniejsze rozumienia systemu.

w filozofii przyrody, w nauce o powstawaniu istot żywych na oznaczenie organizmu zwierzęcego. Słowo „system" odddziaływujące na późniejsze myślenie, można znaleźć w Hellenizmie u Stoików, gdzie kosmos jest definowany jako system sklepienia niebieskiego i ziemi, wraz z żyjącymi w ich obrębie istotami żywymi oraz jako system Bogów, ludzi i rzeczy. U stoików polis jest rozumiane jako system ludzi zamieszkujących ten sam teren i zarządzanych tymi samymi prawami. Najczęściej jednak termin „system” jest stosowany w logice stoickiej: wynik jest systemem założeń i wnioskowania. Cicero przełożył słowo sistema na łacinę jako constructio. W łacinie i średniowieczu występuje tłumaczenie słowa sistema jako systema i pojawia sią pod różnymi znaczeniami.

2 M. Heidegger, Schelling: vom Wesen der menschlichen Freiheit (1809), Gesamtausgabe, Band 42, Hrsg. I. Schüßler, Vittorio Klostermann, Frankfurt am Main 1988, s. 45. Tłumaczenia wszystkich cytatów zamieszczonych w tekście są mojego autorstwa.

3 Ibidem. 
Mówi się o systemach skończonych, zamkniętych i systemach nieograniczonych, otwartych. W systemowym myśleniu filozoficznym wyróżniają się szczególnie systemy idealizmu niemieckiego ${ }^{4}$. W naukach, które wyodrębniły się pierwotnie z filozofii, pojęcie systemu zrobiło zawrotną karierę. Podczas gdy system we filozofii nie spotkał się z szczególnym zainteresowaniem, a filozofowie systemowi stali się ulubionymi chłopcami do bicia, to nie można sobie dzisiaj wyobrazić żadnej dziedziny nauki i życia bez systemu.

\section{Początki systemu}

Pojęcie wolności jest podstawowym pojęciem filozofii, które nie potrzebuje uzasadnienia i odwoływania się do czegoś innego. Myślenie filozoficzne ugruntowane jest $\mathrm{w}$ doświadczeniu wolności. Heidegger stwierdza: „Pojęcie wolności nie znosi się w ogóle z systemem”" System sprzeciwia się wolności, bo potrzebuje dla swojego rozwinięcia założenia metodycznych zasad i odwoływania się do nich. System wyklucza się z wolnościa, ponieważ ma tendencję do podporządkowywania ograniczania i zamykania.

Filozofia ulega skłonności do ujmowania myślenia w stałe formy systemowe. Przeciw skłonności do budowania systemowej filozofii wystąpiła fenomenologia. „To kroczenie ku 'właściwej filozofii', ku ‘naukowej filozofii', albo ku 'filozofii światopoglądowej' ponad tym, co fenomenologiczne, sprzyja temu ujęciu historii filozofii jako następowaniu po sobie i obok siebie systemów"6. Fenomenologia z istoty jest asystemowa. $\mathrm{Na}$ początku paragrafu o metodzie w Sein und Zeit, Heidegger podkreśla, że fenomenologia jest pierwotnie "pojęciem metody" (Methodenbegriff) ${ }^{7}$. Pojęcie fenomenologii jako metody nie odpowiada tematycznemu przedmiotowi filozofii, lecz sposobowi traktowania (Behandlungsart), dotyczy Jak (Wie) jej badania. Fenomenologia źródłowo wyraża nie tematyczny przedmiot, nie „rzeczowe Co (Was) przedmiotów filozoficznego badania" ${ }^{\prime \prime}$, tylko jej sposób badania. Fenomenologiczny sposób badania nie jest „,ani 'punktem widzenia' (Standpunkt), ani 'kierunkiem' (Richtung),

${ }^{4}$ W niemieckiej przestrzeni językowej obok słowa „system” są także w obiegu takie bliskoznaczne terminy, jak. Struktur, Aufbau i Gefüge.

5 M. Heidegger, Schelling: Vom Wesen der Freiheit (1809), Gesamtausgabe, Band 42, Hrsg. I. Schußler, Vittorio Klostermann, Frankfurt am Main 1988, s. 37.

6 M. Heidegger, Grundprobleme der Phänomenologie, Gesamtausgabe, Band 58, Hrsg. H.-H. Gander, Vittorio Klostermann, Frankfurt am Main 2010, .s 233.

7 M. Heidegger, Sein und Zeit, Band 2, Gesamtausgabe, Unveränderter Text mit Randbemerkungen des Autors aus dem „Hüttenexemplar“, Hrsg. Fr. - W. von Herrmann, Vittorio Klostermann, Frankfurt am Main 1977, s. 37.

8 Ibidem. 
ponieważ fenomenologia nie jest żadnym z nich i nie może nigdy się stać, dopóki rozumie siebie samą" ${ }^{\prime 9}$. Fenomenologia jako metoda jest niezależna od treściowych filozoficznych punktów widzenia i kierunków. Dlatego stoi ponad systemami filozoficznymi. Wstępne rozjaśnienie pojęcia fenomenologii w Sein und Zeit kończy się wskazówką: „Wyżej niż rzeczywistość stoi możliwość. Zrozumienie fenomenologii leży jedynie w ujęciu jej jako możliwości"10. Fenomenologiczny sposób traktowania (Behandlungsart), w sensie maksymy badawczej „do rzeczy samych”, jest widziany przez Heideggera w jego charakterze możliwościowym. Jako możliwość stoi fenomenologia wyżej niż jej każdorazowa rzeczywistość, ponieważ jako możliwość może być ona ciągle na nowo ujmowana i podejmowana.

Heidegger usiłuje odpowiedzieć na trzy podstawowe pytania dotyczące systemu: „1. Co w ogóle znaczy system? 2. Jak i w jakich warunkach dochodzi w filozofii do kszałtowania się systemu? 3. Dlaczego właśnie w filozofii niemieckiego idealizmu 'system' jest wezwaniem do walki (Kampfruf) i najbardziej wewnętrznym wymaganiem (innerste Forderung)?"11.

Systemowość może wyrażać się w postaci czystej systematyki, w przypadku, gdy „system filozofii, lecz także system nauk, pojmowany jest całkiem zewnętrznie"12. Filozofia musi ciągle na nowo odrzucać nieprawdziwe postaci systemu i budowanie systemów niewłaściwych „dlatego, że system, w swym prawdziwym sensie, jest właśnie zadaniem filozofii, i to jej właściwym zadaniem"13. System wyrasta ze sposobu filozofowania, z samorozumienia filozofii. Trzeba jednak rozróżniać między systematyką filozoficzną i systemem filozoficznym, między systemami właściwymi i niewłaściwymi, między systemami, które sprzeciwiają się filozoficznej idei krytycznego myślenia i systemami, które wypływają z wewnętrzej istoty filozofii.

Każda filozofia jest systematyczna, ale nie każda jest systemem, i to nie dlatego, że nie jest jeszcze 'gotowa'. Odwrotnie jest tam, gdzie pozornie coś wygląda na system, nie zawsze mamy do czynienia z systematycznym myśleniem, to znaczy filozofią. Z tego wypływa: trzeba w każdym przypadku wiedzieć jasno, co się ma na myśli, kiedy mówi się ‘system"14.

9 Ibidem.

10 Ibidem, s. 52

11 M. Heidegger, Schelling: Vom Wesen der menschlichen Freiheit (1809), Band 42, op. cit., s.44.

12 Ibidem, s. 46.

13 Ibidem, s. 47.

14 Ibidem, s. 51. 
W dziejach filozofii system stał się często warunkiem możliwości systematyczności i w ogóle warunkiem możliwości uprawiania filozofii. Filozofia, nawet wielka filozofia, może się jednak obyć bez systemu.

Cała grecka filozofia jest na to dowodem. Początek zachodniej filozofii pozostał bez systemu; lecz jednocześnie, a nawet właśnie dlatego, to filozofowanie było na wskroś 'systematyczne', to znaczy, prowadzone i niesione przez całkiem określone wewnętrzne złożenie (Fügung) i porządek (Ordnung) stawiania pytań, tego stawiania pytań, które w ogóle stworzyło istotny warunek dla wszelkiej systematyki i możliwości systemu ${ }^{15}$.

Starożytni greccy myśliciele nie zbudowali systemu myślenia, ani nie zaprojektowali systemu dla przyszłego filozofowania. Platon i Arystoteles ustalili jedynie założenia sprzyjające budowaniu systemów. Stworzyli, wbrew swojej woli, podwaliny dla budowania właściwych i niewłaściwych systemów. Mówienie o systemie w filozofii Platona i Arystotelesa jest zafałszowaniem dziejów filozofii w jej początkach. Grecka starożytność zapoczątkowała systematyczność pytania filozoficznego, pozostawiającego myślenie w otwarciu i strzegącego przed schronieniem się w system.

Zwykło się nazbyt pochopnie widzieć systemy w filozofiach średniowiecznych. Tak zwane summy scholastycznych teologów i filozofów nie sa, w interpretacji Heideggera, żadnymi systemami, lecz tylko „formami podręcznikowego przekazu wiedzy"16. Średniowieczne summy, w odróżnieniu od commentationes, disputationes, questiones, mają na celu przedstawienie w sposób uporządkowany i metodyczny, wiedzy przeznaczonej do szkolnego nauczania. Summy średniowieczne w pierwszym rzędzie nastawione są na nauczanie i są tym samym podręcznikami usystematyzowanej wiedzy. Również słynna Summa theologica Tomasza z Akwinu nie jest jakąś konstrukcją systemowa, lecz podręcznikiem, i to dla początkujących, w której przedstawione jest w sposób prosty i uporządkowany to, co jest istotne dla przekazu szkolnej wiedzy ${ }^{17}$.

Teologiczne summy usiłuje się chętnie porównywać do średniowiecznych katedr. To porównanie jest w gruncie rzeczy chybione, gdyż średniowieczne katedry zwężają się ku górze, wychodząc z szerokiego fundamentu aż do ostro zakończonej wieży, zwróconej w kierunku nieba. Tymczasem teologiczne summy wychodzą od prawdy początkowej o stworzeniu i rozszerzają się, jak odwrócony stożek, aż do drobiazgowych wskazań dotyczących życia chrześcijańskiego.

15 Ibidem.

16 Ibidem.

17 Neoscholastyka może już być jednak postrzegana jako system, u którego podłoża leży nastawienie apologetyczne. 
Pomieszanie pojęciowe dotyczące systemu urasta $\mathrm{w}$ bezmiar, kiedy te summy, jako rzekome systemy średniowiecznego myślenia, zostają porównywane z rzeczywistymi systemami Hegla i Schellinga, albo z rzekomymi systemami Platona i Arystotelesa ${ }^{18}$.

Te porównania przeszkadzają zarówno we właściwym rozumieniu myślenia średniowiecza, jak i zrozumieniu istoty i warunków możliwości właściwego systemu.

Jeżeli w średniowiecznym kształtowaniu i porządkowaniu wiedzy występuje jakaś odpowiedniość do systemu, to w sposobie podziału i stopniowania obszarów bytowych, jaki występuje w dziele wielkiego zachodniego myśliciela epoki karolińskiej, Johannesa Scotusa Eriugeny De divisione naturae, napisanym około $860 \mathrm{roku}^{19}$. W dziele tym widoczny jest wyraźnie wpływ filozofii późnogreckiej, neoplatonizmu, który przeforsował się już w filozofii judejsko-greckiej i rzymskiej, a który nie pozostał bez wpływu na wykszałtowanie się późniejszych systemów w filozofii.

\section{System nowożytny}

System wyraża się w systematyzowaniu wiedzy i w usystematyzowanej wiedzy. Wiedza potrzebuje systemu zarówno dla zewnętrznego uporządkowania, jak i dla wewnętrznego porządku.

'System' to nie jest tylko zwykłe uporządkowanie dostępnego materiału wiedzy dla celów prostego nauczania dla początkujaccych. W ogóle system jest nie tylko i nie w pierwszym rzędzie porządkiem dostępnego materiału wiedzy i tego, co warte poznania, dla celów właściwego przekazywania wiedzy, lecz system jest wewnętrznym złożeniem (Fügung) samej wiedzy, jej ugruntowującym rozwinięciem i ukształtowaniem, a właściwiej: system jest, w wiedzy, złożeniem (Fügnug) konstrukcji (Gefüge) i spoiwa (Fuge) bytującego w jego bytowości ${ }^{20}$.

Zewnętrzny sposób uporządkowania wiedzy świadczy o zrozumiałości i komunikatywności wiedzy, niezależnie od jej filozoficznej ważności. Natomiast wewnętrzny sposób usystematyzowania wiedzy należy do jej istoty. Może być miarą wielkości filozoficznego myślenia i prawdziwości filozoficznej wiedzy.

18 M. Heidegger, Schelling: Vom Wesen der menschlichen Freiheit (1809), Band 42, op. cit., s. 49 .

19 Ibidem.

20 Ibidem, s. 49-50. 
Powstanie systemu nie jest dziełem przypadku. System nie mógł się zrodzić w dowolnej epoce. Wykształtowanie się prawdziwych systemów dokonało się w określonym czasie i określonych warunkach.

Możliwość myślenia czegoś takiego, jak system, tak samo jak możliwość koncepcji i rozpracowania (systemu), mają swoje własne warunki. Te (warunki) nie dotyczą niczego innego, jak ujęcia bycia, prawdy i wiedzy w ogóle ${ }^{21}$.

Myślenie systemowe uwarunkowane jest możliwościami filozoficznego rozumienia i wykładni bycia bytu. W epoce nowożytnej urzeczywistniła się możliwość pojawienia się systemu. W nowożytności ukształowały się pierwsze prawdziwe systemy, ugruntowane $\mathrm{w}$ doświadczeniu świata i w byciu człowieka (Dasein). Szukanie systemów w czasie poprzedzającym epokę nowożytną może wypływać z niezrozumienia pojęcia systemu lub błędnej interpretacji systemu $\mathrm{w}$ jego zewnętrznym sensie. System jest znakiem rozpoznawczym czasów nowożytnych. Warunki możliwości nowożytnego systemu są jednocześnie warunkami możliwości powstania nowożytnych nauk.

U podstaw systemów nowożytnych leży, w interpretacji Heideggera, "wola do zbudowania matematycznego systemu rozumu”. Heidegger widzi sześć zasadniczych warunków możliwości wykształtowania się nowożytnego systemu ${ }^{22}$.

1. Panowanie matematyki jako miary dla tego, co naukowe.

2. Ugruntowanie nauki jako kryterium pewności.

3. Ugruntowanie pewności jako samopewności ego cogito.

4. Myślenie, ratio, jako instancja określania bycia.

5. Załamanie się wszechpanowania nauki kościelnej jako miary dla prawdy i nauki.

6. Wyzwolenie człowieka do twórczego podbicia, opanowania i ukształtowania na nowo tego, co bytuje.

Historia powstania tej postaci systemu jest jednocześnie historią powstania nowożytnej nauki, która z istoty swojej jest nauką systemową. W czasach nowożytnych nauki, a także dziedziny publicznego życia, przybierają postać systemów. Racjonalny system, który zapoczątkowała nowożytność, staje się nie tylko panującą formą myślenia, lecz także tworzenia, pracy, życia.

Sposób, zasięg, wymiar czasowy kształtowania się systemu w różnych obszarach poznania natury, tworzenia się państw, urzeczywistniania sztuki i teorii sztuki, w wychowaniu i ugruntowaniu wiedzy systematycznej, w filozofii, jest bardzo różny. Co więcej, także w obrębie filozofii,

21 Ibidem, s. 50.

22 Ibidem, s. 52-58. 
próby budowania systemu wykazują różne usiłowania i odmiennie ukierunkowane rozwinięcia ${ }^{23}$.

Nie można zaprzeczyć, że wiele nauk zawdzięcza swój niebywały postęp właśnie temu, że stały się naukami systemowymi. Od czasów nowożytnych dokonano wielu ważnych odkryć, ponieważ poruszano się w systemie. Istnieją jednak przełomowe odkrycia, które zostały dokonane właściwie wbrew myśleniu systemowemu ${ }^{24}$.

Historyczne wykształtowanie się systemów nie ukazuje ani stopniowego rozwoju jednych systemów, ani upadania innych. Objawia jedynie chwiejną relację między wolą budowania systemu, a rzeczywiście zbudowanymi systemami. Siedemnastowieczne i osiemnastowieczne systemy filozoficzne Descartesa, Malebranchea, Spinozy, Hobbesa, Leibniza nie dają się zestawić $\mathrm{w}$ jednym rzędzie i jednoznacznie ocenić. W czasach nowożytnych jedynym systemem filozoficznym, w dosłownym sensie, jest system Spinozy, który po jego śmierci ukazał się pod znaczącym tytułem: Ethica ordine geometrico demonstrata et in quique partes distincta.

Kształtowanie się systemu w filozofii nowożytnej osiągnęło punkt szczytowy w niemieckim idealizmie (Kant, Schelling, Hegel). Filozofowie idealizmu niemieckiego pierwsze swoje prace poświęcili systemowi. System jest wielkim tematem niemieckiego idealizmu, ale tylko Hegel jest „tym myślicielem, który pomyślał myśli Heraklita gruntownie i do końca, w jedynym systemie filozoficznym, który istnieje w zachodniej filozofii" 25 . System ma w sobie coś nieruchomego, ahistorycznego. Dlatego przeciwieństwem myślenia systemowego jest myślenie dziejowe; myślenie w stawaniu się. Tutaj Heidegger wyraża jednak poważną wątpliwość „Lecz 'stawanie' (jest) także u Hegla, a właśnie tutaj (występuje) system?" 26 . System układa i rozwija się według własnego schematu. Ale czy sam system jako system może podlegać zmianie? Czy system może być jednocześnie schematyczny i dziejowy?

Istotą myślenia idealizmu niemieckiego jest system. Na pytanie „dlaczego 'system' w niemieckim idealizmie jest „wezwaniem do walki" (Kampfruf) i najbardziej wewnętrznym «wymaganiem» (Forderung)" Heidegger odpowiada:

Ponieważ tutaj do określeń systemu, że musi być on matematyczny i racjonalny, doszło jeszcze istotne spostrzeżenie, że taki system mógłby być

23 Ibidem, s. 59.

24 Na przykład teoria względności.

25 M. Heidegger, Hölderlins Hymnen, "Germanien" und "Rhein", Gesamtausgabe, Band 39, Vittorio Klostermann, Frankfurt am Main 1999, s. 129.

26 M. Heidegger, Seminare. Hegel-Schelling, Gesamtausgabe, Band 86, Hrsg. P. Trawny, Vittorio Klostermann, Frankfurt am Main 2011, s. 227. 
w wiedzy znaleziony i ukształtowany tylko wtedy, jeżeli wiedza byłaby wiedzą absolutna. W niemieckim idealizmie 'system' był wyraźnie pojmowany jako wymaganie absolutnej wiedzy. System stanowczo stał się sam absolutnym wymaganiem i dlatego motywem przewodnim filozofii w ogóle ${ }^{27}$.

Absolutność systemu idealizmu niemieckiego oznacza, że posiada on roszczenia do osiaggnięcia całościowej wiedzy o tym, co bytuje. System idealizmu niemieckiego jest wezwaniem do walki z tym, co nie jest racjonalnie. System $\mathrm{w}$ idealizmie niemieckim jest warunkiem koniecznym filozofii i nauki w ogóle.

Przemiana myślenia systemowego XVII i XVIII wieku, w drodze do myślenia systemowego idealizmu niemieckiego na początku XIX wieku, zakładającego rozumienie filozofii jako absolutnego poznania, ugruntowanego $\mathrm{w}$ nieskończonych, twórczych możliwościach rozu$\mathrm{mu}$, zwraca wzmożoną uwagę filozofów na źródłową wiedzę o rozumie. Ta wiedza może być dostępna poprzez nowy namysł nad samym rozumem, który jest dziełem Kanta, usiłującego określić pojęcie syste$\mathrm{mu} z$ istoty rozumu.

Krytyce czystego rozumu Kanta towarzyszy nieustannie namysł nad istotą tego, co matematyczne i matematyki oraz namysł nad odgraniczeniem rozumu matematycznego w ścisłym sensie od rozumu metafizycznego, w którym może być ugruntowana metafizyka, to znaczy, projekt bycia bytów. W Krytyce przewija się „matematyczny” motyw przewodni nowożytnej metafizyki , aby uprzednio z podstawowych zasad określić bycie bytu.

Podstawowe zasady czystego rozumu musza, zgodnie z własnym charakterem, zostać uzasadnione i dowiedzione. Jednocześnie w istocie zasad podstawowych leży to, że przedstawiają one ugruntowaną pomiędzy sobą relację, że do siebie jednolicie przynależą z wewnętrznej jedności. Tego rodzaju jedność według pryncypiów, nazywa Kant systemem² ${ }^{28}$.

27 M. Heidegger, Schelling: Vom Wesen der menschlichen Freiheit (1809), Band 42, op. cit., s.61

28 M. Heidegger, Die Frage nach dem Ding. Zu Kants Lehre von den transzendentalen Grundsätzen, Gesamtausgabe, Band 41, Hrsg. P. Jaeger, Vittorio Klostermann , Frankfurt am Main 1984, s.124. 


\section{Destrukcja systemu}

Destrukcja, w interpretacji Heideggera, jest zaostrzoną i zradykalizowaną krytyką pojęć filozoficznych. Destrukcja systemu nie jest odrzucaniem każdego systemu; jest wymierzona w pewną postać systemu. Poddać destrukcji system, znaczy: pokazać jego granice. Heidegger dokonuje nie tylko destrukcji systemu filozofii idealizmu niemieckiego, lecz w ogóle myślenia systemowego całej filozofii zachodniej.

System idealizmu niemieckiego jest systemem zamkniętym. To zamknięcie nie jest zamknięciem się jedynie w zasadach i twierdzeniach. Heidegger interpretuje system idealizmu niemieckiego jako "zamkniętą konstrukcję (Gefüge) tego, co bytuje, w jego jedynej obecności (Anwesenheit)" ${ }^{29}$. System poruszający się w zamkniętym obrębie tego, co bytuje, nazywa Heidegger systemem ontologicznym. „Pod tym tytułem (ontologia) filozofia uprawia każdorazowo ustanowienie i przedstawienie jakiegoś fachu $w$ obrębie jej systemu" ${ }^{30}$. Każde myślenie rezygnujące $\mathrm{z}$ pytania o bycie samo jest myśleniem systemowym.

System znajduje uzasadnienie i wyjaśnienie w samym sobie. „Każdy 'system' jest 'systemem' tylko jako system absolutny." ${ }^{11}$ Absolutność systemu oznacza, że wszystko podlega systemowaniu, na warunkach, jakie wyznaczyła sobie filozofia systemowa. System zapewnia porządek i stabilność, a jednocześnie odgranicza i podporządkowuje. Z absolutnego charakteru systemu filozoficznego wzięło się widzenie systemów jako modeli dla totalnych systemów politycznych i ideologicznych .

Głoszone przez Nietzschego wypełnienie się metafizyki nowożytnej ma związek, w wykładni Heideggera, z rozumieniem filozofii jako absolutnego systemu.

„Dlatego występują obydwa znaki charakterystyczne istoty wypełnienia się nowożytnej metafizyki: a) Sposób, w jaki pojęcie filozofii określa się przez system absolutny, b) Sposób, w jaki system, w najbardziej skrajnym wypełnieniu się metafizyki (Nietzsche), został wprowadzony w nieistotę i pozornie zjednoczony." ${ }^{32}$

Absolutyzowanie systemowe metafizyki zachodniej nazywa Nietzsche "wolą do władzy” (Der Wille zur Macht), to znaczy: pragnienie absolutnego panowania rozumu jako ratio. Dla Nietzschego system

29 M. Heidegger, Seminare Hegel - Schelling,, Band 86, op. cit., s. 227.

30 M. Heidegger, Einführung in die Metaphysik, Gesamtausgabe, Band 40, Hrsg. P. Jaeger, Vittorio Klostermann, Frankfurt am Main 1983, s. 44.

31 M. Heidegger, Metaphysik und Nihilismus, Gesamtausgabe, Band 67, Hrsg. H.-J. Friedrich, Vittorio Klostermann, Frankfurt am Main 1999, s. 158.

32 Ibidem. 
jest wyrazem antropocentryzmu i antropomorfizmu. Mówi o „woli do systemu" (Der Wille zum System) i o myśleniu racjonalnym, które zostało opanowane przez "intellectus systematiens" ${ }^{\prime 3}$. System w wypowiedziach Nietzschego ma w sobie coś nienormalnego, niegodnego i niemoralne$\mathrm{go}^{34}$. Heidegger nie widzi w Nietzschem właściwie przeciwnika syste$\mathrm{mu}$, ponieważ nie usiłował on pozytywnie przezwyciężyć systemu. Nietzsche zrezygnował z istotnej krytyki systemu. „Tym samym wydaje się, że rezygnacja ze systemu (u Nietzschego) została podniesiona do rangi podstawowego twierdzenia" ${ }^{35}$. To, co mówi Nietzsche na temat syste$\mathrm{mu}$, nie ma według Heideggera większego znaczenia, ponieważ nie trafia w sedno rzeczy. Poza tym nie wiadomo, czy Nietzsche ma na uwadze system idealizmu niemieckiego, czy także inne systemy, na przykład, systemy moralne. A istota niemieckiego idealizmu nie polega tylko na tym, że był systemowy. Nietzschego stanowisko wobec systemu różni się zasadniczo od stanowiska Kierkegaarda, którego chętnie zwykło widzieć się razem z Nietzschem jako przeciwnika systemu.

Kierkegaard natomiast jest nastawiony całkowicie przeciwnie wobec systemu. Ale 1. Pod pojęciem 'systemu' rozumiany jest tylko system heglowski, a ten jest (przez niego) błędnie rozumiany. 2. Odrzucenie systemu przez Kiekegaarda nie jest filozoficzne, nie w zamiarze filozoficznym, lecz jest religijne ${ }^{36}$.

To, co Kierkegaard wypowiada na temat heglowskiego systemu jest dla Heideggera "bogate duchowo, ale filozoficznie bez znaczenia”" Znaczenie Kierkegaarda dla filozofii widzi Heidegger w zupełnie innym obszarze (określenie pojęcia egzystencji) niż krytyka i odrzucenie systemu. System musi być przede wszystkim widziany jako problem filozoficzny.

33 „Wola do systemu: u filozofa, mówiąc w sposób moralny, subtelniejsze zepsucie, choroba charakteru; mówiąc - w sposób niemoralny, jego wola okazania się głupszym niż jest - głupszym, to znaczy, mocniejszym, prostszym, bardziej władczym, bardziej niedokształconym, rozkazującym, tyranizującym...". F. Nietzsche, Nachgelassene Fragmente, (Sommer 1872 - Ende 1874, 19 (248), Kritische Gesamtausgabe, Hrsg. G. Colli/ M. Montinari, (1967), 3/ 4, s. 85.

34 "Nie mam zaufania do systematyków i schodzę im z drogi. Wola do systemu jest brakiem prawości (Rechtschaffenheit). F. Nietzsche, Nachgelassene Fragmente (Herbst 1887 - März 1888) 9(188), Kritische Gesamtausgabe , Hrsg G. Colli/ M. Montinari, 1967, 8/2, s. 114

35 M. Heidegger, Schelling. Vom Wesen der menschlichen Freiheit (1809), Band 42, op. cit., s. 42.

${ }_{36}$ Ibidem.

37 Ibidem, s. 43. 
Uzasadniona filozoficzna rezygnacja z systemu może wypływać tylko $z$ istotowego wglądu $\mathrm{w}$ system $\mathrm{i}$ istotnego uznania systemu; uzasadniona rezygnacja jest wtedy czymś zasadniczo odmiennym niż zwykła obojętność wobec systemu, niż zwykła bezradność wobec pytania o system ${ }^{38}$.

W późniejszym rozprawianiu się z systemem, krytyka systemu, dokonana przez Nietzschego, została wykorzystana, a zarazem nadużyta. „Odrzucono 'system' jako twór ramowy, na korzyść 'systematyki', która jest przecież tylko ukrytą formą 'naukowego' myślenia dla tego, co filozoficzne" ${ }^{\prime 39}$. Wielu krytyków systemu (Dilthey, Jaspers, Hartmann) pod wpływem Nietzschego kwestionuje system w filozofii, ale chce zachować jej naukową systematyczność.

Aby pożegnać się z myśleniem systemowym tradycji filozoficznej Zachodu wprowadza Heidegger termin „decyzja”. Decyzja nie jest wyborem, ani postanowieniem. Nie wiąże się z wolnością jako zdolnością do rozstrzygania i nie jest podjęta w sensie moralno-antropologicznym. Decyzja przynależy do myślenia prawdy bycia.

Kiedy podjęta zostaje 'decyzja' przeciwko 'systemowi', to jest to przejście z nowożytności do innego początku. Jeśli 'system' zawiera istotną charakterystykę nowożytnej bytowści bytującego (przedstawieniowość), natomiast 'decyzja' ma na uwadze bycie dla bytującego, a nie tylko bytowość z bytującego, to de-cyzja (Ent-scheidung) jest 'bardziej systematyczna' niż każdy system, to znaczy, źródłowym przeznaczeniem bytującego jako takiego, z istoty bycia $(\operatorname{Seyn})^{40}$.

Decyzja wyraża się w albo-albo dotyczącym rozstrzygnięć historii filozofii i dziejów myślenia bycia. Sprzeciwienie się nowożytnemu systemowi na rzecz systematyczności myślenia bycia jest jedną $\mathrm{z}$ decyzji w obrębie wydarzenia decydowania myślenia prawdy bycia.

Cała filozoficzna tradycja eupropejska, zwłaszcza w postaci filozofii nowożytnej, jest w wykładni Heideggera jednym wielkim myśleniem systemowym, poruszającym się $\mathrm{W}$ „,systemie logiki" ${ }^{41}$, rozumiejącym logos jako ratio. System logiki, wywodzącej się z ratio „rozumie myślenie jako przedstawianie sobie bytu $\mathrm{w}$ jego byciu" ${ }^{42}$. Przeciw tego rodzaju „systemowi" występuje Heideggera myślenie bycia.

Filozofia zachodnia jako nauka systemowa i systematyczna, osiągnęła punkt szczytowy $\mathrm{w}$ niemieckim idealizmie, a jednocześnie natra-

38 Ibidem, s. 43.

39 M. Heidegger, Beiträge zur Philosophie (Vom Ereignis), Gesamtausgabe, Band 65, Hrsg. Fr.-W. von Herrmann, Vittorio Klostermann, Frankfurt am Main 2004, s. 89 .

40 Ibidem

41 Ibidem, s. 348.

42 Ibidem. 
fiła na granice filozoficznej systematyki. W interpretacji Heideggera takie filozofowanie systemowe nie ma przed sobą żadnej przyszłości.

Epoka 'systemów' w filozofii skończyła się definitywnie. Nie dlatego, że treść wiedzy narosła zbyt ogromnie, by móc ją w miarę przejrzyście uporządkować, lecz dlatego, że istota wiedzy będzie się przeobrażać, w odróżnieniu i przeciwieństwie przede wszystkim do wiedzy nowożytnej, która domaga się 'systematyki' jedynie samej w sobie i dla samej siebie. $\mathrm{W}$ wielkim początku zachodniego myślenia nie było [...] jeszcze systemów i po skończeniu się tego pierwszego początku nie będzie już systemów ${ }^{43}$.

Heidegger nie jest właściwie przeciwnikiem systemu. Uważa system, przede wszystkim, system idealizmu niemieckiego jako część dziejów bycia filozofii. Usiłuje pozytywnie nawiązać do czasów, kiedy myślenie filozoficzne mogło obyć się bez systemu. W Heideggera projekcie myślenia "po skończeniu się pierwszego początku” nie ma potrzeby budowania innej, jakościowo lepszej postaci systemu, nie ma potrzeby innego, solidniejszego systematycznego filozofowania. „Ponieważ głębsze konieczności prowadzą myślenie i pytanie, i ponieważ jego wewnętrzny porzadek i ścisłość (Strenge) będzie bardziej ukryta niż pozornie nie do przebicia, bo przejrzysta, zawartość systemu" ${ }^{\prime 4}$. Ramy systemu i podstawa systematyzowania zostają zastąpione wewnętrznym porządkiem $i$ ścisłościa. Ścisłość wypowiedzi myślenia z nowego, innego początku nie jest dokładnością, trafnością, ostrością filozoficznej artykulacji. Ta ścisłość jest akrybią wypowiedzi wypływającą z doświadczenia istoty prawdy bycia.

\section{4. "Systemowość" myślenia bycia.}

W Beiträge zur Philosophie (Vom Ereignis) Heidegger przedkłada projekt myślenia bycia jako wydarzenia (Ereignisdenken). Dzieło to podejmuje, jak autor sygnalizuje zaraz na początku, "pytanie o prawdę bycia (Seyn)" jako „dziejów myślenia bycia (Seyn)”"45. „Byciowo-dziejowe” (seynsgeschichtlich) oznacza , że „istota bycia” jest rozumiana „dziejowo"46. Dlatego „istota” (Wesen) jest doświadczona jako „istototowanie” (Wesung) bycia, które Heidegger nazywa „wy-darzeniem” (Er-eignis) ${ }^{47}$. Beiträge

${ }^{43}$ M. Heidegger, Grundfragen der Philosophie, Gesamtausgabe, Band 45, Hrsg. Fr.W. von Herrmann, Vittorio Klostermann, Frankfurt am Main 1992, s. 144.

44 Ibidem, s. 145.

45 M. Heidegger, Beiträge zur Philosophie (Vom Ereignis), Band 65, op. cit., s. 3.

46 Ibidem, s. 32.

47 Ibidem. 
podejmują po raz pierwszy myślenie byciowo-dziejowe (seingeschichliches Denken) prawdy bycia i jego istotowania.

Beiträge można słusznie nazwać drugim wielkim dziełem po Sein und Zeit. Dzieło to, o bezbarwnym i niewiele mówiącym tytule, zawiera, po fundamentalno-ontologicznym rozpracowaniu pytania o bycie w Sein und Zeit, pierwsze przekształcenie pytania o bycie, na drodze dziejów bycia. Fundamentalna ontologia miała za zadanie wytyczyć horyzontalną drogę pytania o bycie przy pomocy hermeneutyki fenomenologicznej Dasein. Dziejowe myślenie bycia rozwija się w Beiträge wertykalnie, z doświadczenia wydarzenia (Ereignis) bycia. W wykładni Heideggera "Ereignis" jest wydarzeniem nie w sensie zdarzenia (Vorkommnis) lub wydarzenia (Geschehen, Geschehnis), którego można być uczestnikiem lub świadkiem. Wydarzenie (Ereignis) i wydarzać się (ereignen) są do pomyślenia, $\mathrm{w}$ ich charakterze wydarzeniowym, przez spojrzenie na własność (Eigentum). Własność oznacza: „przynależność” (Zugehörigkeit) ${ }^{48}$. Wydarzenie jest myślową wzajemną przynależnością Da-sein do prawdy bycia.

Już od wiosny 1932, a więc w pięć lat po ukazaniu się Sein und Zeit, gotowy jest plan Beiträge. Heidegger sam określa szczególne miejsce Beiträge na jego myślowej drodze, kiedy jesienią 1962 na seminarium w Todtnauberg zauważa: „Odniesienia i powiązania, stanowiące o budowli istoty wydarzenia, zostały wypracowane między 1936 a 1938"49. Wskazuje na wyjątkowe znaczenie Beiträge, które ukazały się po raz pierwszy drukiem 1989, dla rozpoczynającej wraz z nimi drugiej drogi pytania o bycie. ,'Beiträge' pytają na torze, który zostaje wytyczony dopiero poprzez przejście do innego początku, w stronę którego myślenie zachodnie teraz się przesuwa" ${ }^{50}$. Myślenie bycia jako wydarzenia jest przejściem do innego początku myślenia. W Sein und Zeit jest ukryta zapowiedź przyszłego myślenia bycia jako myślenia bez pośrednictwa myślenia bycia bytu. Jesteśmy w drodze do tego myślenia, jesteśmy w przechodzeniu do tego myślenia, któremu Beiträge wyznaczają kierunek. W myśleniu dziejów bycia nie chodzi tylko o myślenie sensu istoty samego bycia, lecz także o myślenie sensu bytującego, którego pozyskanie było związane z nowożytnym systemem i w ogóle z myśleniem systemowym. W interpretacji Heideggera, nowożytny systemowy sposób filozofowania osiągnął kres: „Czas ‘systemów' przeminął”51. Przeminął

48 Ibidem, s. 263.

49 M. Heidegger, Protokoll zu einem Seminar über den Vortrag "Zeit und Sein“, w: M. Heidegger, Zur Sache des Denkens, Gesamtausgabe, Band 14. Text der durchgesehenen Einzelausgabe mit Randbemerkungen des Autors aus seinem Handexemplar, Hrsg. Fr. -W. von Herrmann, Vittorio Klostermann, Frankfurt am Main 2007, s. 46.

50 M. Heidegger, Beiträge zur Philosophie (Vom Ereignis), Band 65, op. cit., s. 4.

51 Ibidem, s. 5. 
czas budowania systemów ontologicznych. Musi nadejść czas budowania postaci istoty tego, co bytuje z prawdy bycia samego.

W Beiträge Heidegger rozwija problem systemu na drodze myślenia dziejów bycia. Myślenie dziejów bycia jako wydarzenia zawiera swój porządek, który stoi poza alternatywą: system - bez systemu.

Myślenie to i rozwinięty przez nie porządek stoi poza pytaniem, czy przynależy do niego jakiś system, czy nie. 'System' jest tylko możliwy w orszaku władzy myślenia matematycznego (w szerokim sensie). Myślenie, które stoi poza tym obszarem i odpowiadającym mu określeniem prawdy jako pewności, jest zatem istotnie bez systemu, nie-systematyczne; ale przez to nie dowolne i bezładne. Nie-systematyczne oznacza wtedy tylko tyle, co 'bezładne' i nie uporządkowane, mierząc według systemu ${ }^{52}$.

System myślenia filozoficznego, od Descartesa po Hegla, nosi w sobie "przedstawieniowość", jako „znak charakterystyczny nowożytnej bytowości bytującego" ${ }^{53}$. Myślenie dziejów bycia jest właśnie „przejściem z nowożytności do innego początku" ${ }^{\prime 54}$, w którym bytowość bytującego zostaje pomyślana i określona z istotności (Wesung) prawdy bycia jako wydarzenia. Pożegnanie w myśleniu bycia jako wydarzenia rozumu jako miary dla bytującego zawiera pożegnanie się z systemem jako systemem rozumu. To pożegnanie udaje się w przemieniony wewnętrzny porządek, który wypływa z doświadczenia istoty prawdy bycia jako wydarzenia. Myślenie bycia samego kieruje się „systemem” w szczególnym sensie. Myślenie dziejów bycia kieruje się własnymi roszczeniami, własną systematyką i własnym rygorem. Myślenie bycia zapoczątkowało inną ścisłość niż ta, którą znała do tej pory filozofia systemowa.

Początkowe myślenie w innym początku, ma innego rodzaju ścisłość: wolność składania (Fügung) swoich spoiw (Fugen). [...] Ścisłość tej ostrożności jest inna, niż 'dokładność' wolno wypuszczonego, każdemu jednakowego i obojętnego 'mędrkowania', z jego, koniecznymi dla takich wymagań pewności, wynikami. Tutaj występuje konieczność tylko dlatego, że roszczenie prawdy zadowala się prawidłowościa wyprowadzania i dopasowania do namierzonego i obliczalnego porządku" $u^{\prime \prime 5}$.

Myślenie bycia jako wydarzenia pozostawia za sobą matematyczną ścisłość, „filozofię jako naukę ścisłą”, wymuszoną precyzję filozoficznej wypowiedzi. Ścisłość myślenia bycia jako wydarzenia artykułowana jest we własnej ostrości.

52 Ibidem, s. 65.

53 Ibidem, s. 89.

54 Ibidem.

55 Ibidem, s. 65. 
Ostrość mówienia w tym myśleniu i prostota kształtującego słowa, mierzą się według pojęciowości, która odrzuca każdą zwykłą wnikliwość jako pustą natrętność. Pojmowane jest to, co tutaj zawsze i jedynie jest do pojmowania, bycie, każdorazowo w złożeniu (Fügung) owych spoiw ( $F u$ gen). Dostojna wiedza takiego myślenia, nie da się nigdy wypowiedzieć w jednym zdaniu. Ale tak samo, wiedza ta nie może być pozostawiona na pastwę jakiegoś nieokreślonego, migoczącego przedstawiania. Pojęcie jest tu pierwotnie 'kwintesencja' (Inbegriff) i nią właśnie najpierw i zawsze, odniesioną do towarzyszącego współujęcia zwrotu (Kehre) w wydarzeniu ${ }^{56}$.

Pojęcia myślenia bycia nie są przedstawieniami rzeczy. Myślenie bycia jest myśleniem pojęciowym, którego pojęcia zawierają ekstrakty sensu i istotności prawdy. Pojmowaniu i wypowiedzi myślenia bycia jako wydarzenia odpowiada własne pojęciowanie, które ujmuje sens istoty prawdy bycia. W swoim późniejszym myśleniu, zamiast o pojęciach, Heidegger będzie mówił o „znakach”, które wyrażają istotny sens, a jednocześnie wskazują na rzecz, to znaczy, prowadzą myślenie na drodze.

W projektowym zarysie (Aufriß) wewnętrznego porządku pytania o prawdę bycia występują: spoiwo (Fuge) i konstrukcja (Gefüge), do których należy 6 złożeń (Fügungen):

\author{
Oddźwięk (der Anklang) \\ Zagranie (das Zuspiel) \\ Skok (der Sprung) \\ Założenie (die Gründung) \\ Przyszli ( die Zukünftigen) \\ Ostatni Bóg (der letzte Gott)
}

Oddźwięk (Anklang) ma swój zasięg w to, co byłe i to, co będzie, a zatem swoją siłę uderzenia w to, co odbywa się poprzez zagranie (Zuspiel). Zagranie bierze swoją konieczność dopiero z oddźwięku biedy porzucenia bycia. Oddźwięk i zagranie są podłożem i polem dla pierwszego odskoku (Absprung) początkowego myślenia do skoku (Sprung), do istotowania (Wesung) bycia. Skok otwiera najpierw nieprzemierzone oddalenia i zakrycia tego, ku czemu ugruntowanie (Grüngung) Da-sein, zgodnie z przyzwaniem wydarzenia, musi się przedrzeć. Wszystkie te sploty muszą się sprawdzić w takiej jedności z uporczywości w Da-sein, która charakteryzuje bycie przyszłych (Zukünftigen). Oni przejmują i przechowują wzbudzoną przez przyzwanie (Zuruf) przynależność do wydarzenia i jego zwrotu (Kehre) i tak przyjdzie im stanąć przed skinieniem (Winke) ostatniego Boga (des letzten Gottes) ${ }^{57}$.

Oddźwięk dotyczy tego, co zostało zapoczątkowane w czasach nowożytnych i współcześnie święci tryumfy: porzucenie i zapomnienie by-

56 Ibidem, s. 64.

57 Ibidem. s. 82. 
cia, myślenie zastąpione postępem techniki, czas pozbawiony pytania, manipulowanie natura, wyższość przeżycia nad myśleniem. Zagranie jest włączeniem się do gry myślenia pierwszych Greków. Skok oznacza gwałtowne przejście do drugiego początku, jakim jest myślenie bycia jako wydarzenia. Ugruntowanie jest zakorzeniem Da-sein w prawdzie bycia jako wydarzenia. Przyszli są tymi, którzy będą zdolni do myślenia bycia jako wydarzenia i wszystkiego, co może być pomyślane z myślenia bycia samego. Ostatni Bóg - będzie inny niż dotychczasowi znani Bogowie. Ostatni Bóg znaczy: ostateczny, w obecności którego rozstrzygną się losy ziemi.

Konstrukcja, złożenia i spoiwo tworzą „metasystemową” strukturę myślenia bycia jako wydarzenia. Wzajemnie są do siebie odniesione i nierozłącznie przynależą do siebie.

Sześć złożeń spoiwa istnieje każde dla siebie, lecz tylko, aby uczynić istotną jedność bardziej przenikliwą. W każdym z sześciu złożeń usiłuje się powiedzieć każdorazowo to samo o tym samym (das Selbe), ale każdorazowo z innego obszaru istoty tego, co nazywa wydarzenie ${ }^{58}$.

Myślenie bycia jako wydarzenia poprzez jedność w różnorodności złożeń wypowiada zawsze tę samą prawdę bycia. Myślenie bycia jako wydarzenia mówi ciągle inaczej o tej samej prawdzie bycia.

Tradycyjne myślenie myśli i wypowiada bycie różnych bytów na różne sposoby. Heideggera myślenie bycia usiłuje myśleć i wypowiadać tak samo, ale z różnych doświadczeń istoty, tę samą prawdę bycia jako wydarzenia ${ }^{59}$.

System jest wyrazem metodycznej orientacji filozofii. W samorozumieniu myślenia bycia jako wydarzenia, nie ma już mowy o metodzie. W miejsce metodycznego rozważania pojawia się "namyst na drodze" (Besinnung auf dem Weg) jako drodze myślenia ${ }^{60}$. Mowa o drodze nie jest $\mathrm{w}$ dziejowym myśleniu bycia metaforycznym sposobem wyrażania się. Droga jest istotnym sensem metody. „Droga” jest słowem nośnym w złożeniu słownym „metoda” (meta-odos). Problem metody stanie się w myśleniu bycia jako wydarzenia, problemem namysłu-na-drodze. Ponieważ to, co w myśleniu bycia jest „drogą", nie jest porównywalne

58 Ibidem, s. 81-82.

59 „Wiele podróżujący sofista pyta Sokratesa: «Ciągle tu jeszcze stoisz i mówisz ciągle to samo? Ułatwiasz sobie sprawę» Sokrates odpowiada: «Ależ nie, to wy sofiści ułatwiacie sobie sprawą bo opowiadacie ciągle to, co nowe i najnowsze i zawsze coś innego. Trudno natomiast jest opowiadać to samo, a najtrudniej: mówić o tym samym to samo»". M. Heidegger, Zollikoner Seminare, Hrsg. M. Boss, Vittorio Klostermann, Frankfurt am Main 2006, s. 30.

60 M. Heidegger, Besinnung, Gesamtausgabe, Band 66, Hrsg. Fr.-W. von Herrmann, Vittorio Klostermann, Frankfurt am Main 1997, s. 15. 
ani z nowożytnym myśleniem metodycznym filozofii, ani myśleniem nauk, a nawet zostaje mu przeciwstawione, dlatego też Heidegger nie używa już słowa „metoda”, na drodze namysłu, lecz posługuje się nim tylko w sensie nowożytnego rozumienia metody.

\section{Bibliografia}

Heidegger M., Sein und Zeit, Band 2, Gesamtausgabe, Hrsg. von Fr.-W. von Herrmann, Vittorio Klostermann, Frankfurt am Main 1977.

Heidegger M., Holzwege, Band 5. Gesamtausgabe, Hrsg. von Fr.-W. von Herrmann, Vittorio Klostermann, Frankfurt am Main 2003.

Heidegger M., Logik. Die Frage nach der Wahrheit, Band 21, Gesamtausgabe, Hrsg von W. Biemel, Vittorio Klostermann, Frankfurt am Main 1995.

Heidegger M., Der deutsche Idealismus (Fichte, Schelling, Hegel) und die philosophische Grundlage der Gegenwart, Band 28, Gesamtausgabe, Hrsg. von C. Strube, Vittorio Klostermann, Frankfurt am Main 1997.

Heidegger, Die Frage nach dem Ding. Zu Kants Lehre von den transzendentalen Grundsätzen, Band 41, Gesamtausgabe, Hrsg. von P. Jaeger, Vittorio Klostermann, Frankfurt am Main 1984.

Heidegger M., Schelling: Vom Wesen der menschlichen Freiheit (1809), Band 42, Gesamtausgabe, Hrsg. von I. Schüßler, Vittorio Klostermann, Frankfurt am Main 1988.

Heidegger M., Ontologie. Hermeneutik der Faktizität, Band 63, Gesamtausgabe, Hrsg. von K. Bröcker - Oltmanns, Vittorio Klostermann, Frankfurt am Main 1988.

Heidegger M, Beiträge zur Philosophie (Vom Ereignis), Band 65, Gesamtausgabe, Hrsg. von Fr.-W. von Herrmann, Vittorio Klostermann, Frankfurt am Main 2003.

Heidegger M., Besinnung, Band 66, Gesamtausgabe, Hrsg. von Fr.-W. von Herrmann, Vittorio Klostermann, Frankfurt am Main 1997.

\section{Streszczenie}

\section{System a metasystemowe myślenie bycia Martina Heideggera}

\section{Słowa kluczowe}

Heidegger; system; system niemieckiego idealizmu; destrukcja systemu; myślenie bycia; metoda; konstrukcja; złożenie i spoiwo „systemu” myślenia bycia jako wydarzenia 
System jest pojęciem metodycznym filozofii, która ustala prawa i reguły dla systematycznego postępowania. Zródłowe, greckie znaczenie systemu jako „zestawienia razem”, można rozumieć przynajmniej w trojaki sposób: 1. Wewnętrzna struktura tworząca jedność tego, co porządkuje z tym, co jest porządkowane, 2. Czysto zewnętrzny układ porządkujący, 3. Konstrukcja ramowa. System w filozofii przybierał różne formy i znaczenia, zanim osiągnął swoją dojrzałą postać w filozofii niemieckiego idealizmu. Właściwy i istotny system nie wypełnia się tylko w systematyzowaniu i systematyce. Początkowa grecka filozofia, która stworzyła podwaliny pod przyszłe systemy, mogła obyć się bez systemu, ponieważ kierowała się wewnętrznym porządkiem i ścisłością pytania. Systemy tradycji filozoficznej są systemami myślenia poruszającego się $\mathrm{w}$ zamkniętej przestrzeni bytowej i przedstawiającymi sobie to, co bytuje. Heideggera myślenie bycia jako wydarzenia stoi poza alternatywą system - brak systemu, bo jest antycypująco prowadzone własną metasystematyką na drodze namysłu nad prawdą bycia. Metasystematyczne myślenie bycia otwiera dopiero możliwość myślenia tego, co bytuje.

\section{Summary}

\section{System and meta systemic thinking of Martin Heidegger}

\section{Keywords}

Heidegger; system; being; method; event

Heidegger tries in his philosophy of the system to answer these questions: What's the system? How and under what conditions it comes to the creation of systems? Why is this system in the philosophy of German idealism an internal demand? System derives from the Greek and means „I put together". Later, the word system is used in the field of knowledge, science, and especially in the philosophy. In philosophy, we have to distinguish between the actual and the apparent systems. The first Greek philosophy had no system, but it was „,systematically" because it was led by a certain order and composition of questioning. The first true systems have arisen in modern times. Those were the rational systems of German idealism, which are also systems of modern sciences. Heidegger announces the end of the system, which is a system of thought, as an idea of what is. Instead of it, a system is arising, which structure, Fugue and joining are founded in the thinking of being as event. 